\title{
Nitrogen deposition suppresses fungal biomass and oxidase activity in faeces of the millipede Spirobolus formosae in a temperate forest
}

\author{
Mengru Wang, Shenglei Fu, Hongzhi Zhang, Meina Wang, Haixiang Xu, Leilei Shi* \\ Laboratory of Geospatial Technology for the Middle and Lower Yellow River Regions, College of Environment and Planning, \\ Henan University, Kaifeng 475004, China
}

\section{ARTICLE INFO}

Article history:

Received May 20, 2018

Revised September 13, 2018

Accepted September 29, 2018

\section{Keywords:}

$\mathrm{N}$ deposition

Microbial community structure

Phenol oxidase

Peroxidase

Millipede faeces

Macroarthropods

PLFA

\begin{abstract}
A B S T R A C T
Atmospheric nitrogen $(\mathrm{N})$ deposition has increased dramatically since the industrial revolution due to human activities. In terrestrial ecosystems, excess nitrogen inputs can greatly affect soil chemical properties, plant growth, and activities of soil microbes and fauna. Millipedes can fragment and consume large quantities of litter, and they regulate nutrient cycling and affect soil fertility through excretion of faeces. Many soil fauna graze on the faeces of millipedes as a part of the soil food web. The decomposition and stabilization of these millipede faeces are especially important in soil carbon dynamics and nutrient cycling, and these processes rely heavily upon microbial activity. However, very few studies have investigated how microbial community structure and oxidase activity of millipede faeces respond to climate change, especially $\mathrm{N}$ deposition. Therefore, we designed a microcosm study to investigate this question, which included two treatments, $\mathrm{N}$ addition treatment and control (without $\mathrm{N}$ addition). We found that: (i) microbial community structure in millipede faeces was altered and the biomass of fungi and actinomycetes in faecal pellets were significantly reduced after $\mathrm{N}$ addition, but bacteria still dominated in millipede faeces after $\mathrm{N}$ addition, (ii) oxidase activity was suppressed in response to $\mathrm{N}$ addition, and (iii) microbial community structure and oxidase activities were significantly correlated to organic carbon and dissolved total nitrogen of faeces. All these changes suggest that millipede excretion activities under nitrogen deposition contribute to carbon stabilization and reduction in greenhouse gas emission owing to the significant role of fungi and associated oxidase in carbon mineralization. It is noteworthy to pay more attention to the function of saprotrophic invertebrates in future $\mathrm{N}$ deposition studies.
\end{abstract}

(c) Higher Education Press 2019

\section{Introduction}

Atmospheric nitrogen $(\mathrm{N})$ deposition has increased dramatically since the industrial revolution due to human activities (Fields, 2004). With rapid economic growth in the last four

\footnotetext{
* Corresponding author

E-mail address: shileilei1985@163.com (L.L. Shi)
}

decades, at present, China is the country experiencing the most serious $\mathrm{N}$ deposition, which is predicted to exacerbate in the future, especially in the regions of industrialization and agricultural intensification (Liu et al., 2013; Jia et al., 2014). In terrestrial ecosystems, excess $\mathrm{N}$ inputs can greatly affect abiotic and biotic soil properties (Shi et al., 2016). Many previous studies, however, focused on the effects of $\mathrm{N}$ deposition on soil microbes, e.g., a meta-analysis showed that microbial biomass is reduced by $15 \%$ under $\mathrm{N}$ deposition (Treseder, 2008). Nevertheless, how $\mathrm{N}$ deposition affects soil 
fauna and their activities has been rarely studied, especially in terms of the saprophagous macroarthropods like millipedes.

Millipedes (Diplopoda) are one of the most diverse groups of terrestrial organisms with over 12000 described species (Sierwald and Bond, 2007). As "litter transformer," millipedes play vital roles in various ecosystem functions due to their capability of fragmenting and consuming large amount of plant litter. Owing to their low assimilation efficiencies, much of the ingested litters is egested as faeces (David, 2014). These faeces mainly consist of undigested litter, mineral particles, and all kinds of microorganisms (Tajovsky et al., 1992; Oravecz, 2002). The decomposition and stabilization of these millipede faeces are especially important in soil carbon dynamics and nutrient cycling. These millipede faeces are both a source and a sink for carbon and nutrients (i.e., nitrogen and phosphorus). Some previous studies have demonstrated that millipede faeces decompose more rapidly than the pre-ingested litter (David, 2014). Such a transformation of litters to faeces would accelerate nutrient cycling in organic matter. However, other studies have suggested a relatively low decomposition rate of millipede faeces when compared with un-ingested litter, which could contribute to soil carbon sequestration and stabilization (Rawlins et al., 2007). The rapid decomposition versus stabilization of millipede faeces is, in fact, regulated by various factors, such as the physical and chemical properties of the faeces (Rawlins et al., 2006). Apart from these abiotic factors, the microbial community structure and enzyme activities in millipede faeces are responsible for the decomposition or stabilization of these faeces to a large extent. Millipedes are one of the most abundant groups of soil macroarthropods in temperate forests in central China, where suffers from severe nitrogen deposition (Liu et al., 2013). Previous studies in temperate forests showed that millipedes could process large quantities of plant litter and produce large amount of faecal pellets, which are "hot spots" of microbial activities (Maraun and Scheu, 1996). However, the fate of the microbial community and activity in these faeces under nitrogen deposition remains unknown. To the best of our knowledge, there are no studies till date investigating how $\mathrm{N}$ deposition affects microbial community and enzyme activity in faeces produced by millipedes. Considering the importance of millipede faeces in the cycling of carbon and other key nutrients (e.g., N and P), and the central role of microbial community and activity in decomposition of millipede faeces, it is urgently necessary to study this important issue.

Therefore, we conducted a microcosm experiment to explore how microbial community and enzyme activity in millipede faeces of change under nitrogen deposition in a temperate forest. We hypothesized that nitrogen deposition would suppress fungal biomass and decrease oxidase activity in millipede faeces because the input of excess nitrogen would acidify the environment (Shi et al., 2018) and enhance the competitive ability of bacteria (Carreiro et al., 2000), which are both unfavorable for fungi.

\section{Material and methods}

\subsection{Millipede, litter, and soil collection}

The samples used in the present study were collected in a temperate forest in Jigongshan National Nature Reserve $\left(31^{\circ} 46^{\prime}-31^{\circ} 52^{\prime} \mathrm{N}, 114^{\circ} 01^{\prime}-114^{\circ} 06^{\prime} \mathrm{E}\right)$ in Henan Province, Central China. The mean annual precipitation in the sampling area is $1119 \mathrm{~mm}$ and the mean temperature is $15.2^{\circ} \mathrm{C}$ (Shi et al., 2016). The reserve is covered by a mixed deciduous forest. Quercus variabilis (Blume 1850) is the dominant canopy tree species. The soil in the reserve is Cambisols based on the FAO soil classification system (IUSS Working Group WRB., 2015). The background rate of $\mathrm{N}$ deposition in precipitation is about $19.6 \mathrm{~kg} \mathrm{~N} \mathrm{ha}^{-1} \mathrm{yr}^{-1}$ in this region. A large canopy nitrogen addition experiment was established in this reserve (Zhang et al., 2015).

Spirobolus formosae (subsp. formosae Keeton, 1960) (Spirobolida) (Fig. 1), as the most abundant and widely distributed millipede species in this region, was used in our experiment (Ye et al., 2014). This species is very large in size, growing up to $140 \mathrm{~mm}$ in length, and feeds on half-decayed leaf litter. The millipedes were collected in May 2017 by hands and transported to the laboratory. Before the experiment, all the millipedes were maintained in a large plastic box $(50 \mathrm{~cm} \times$ $30 \mathrm{~cm} \times 20 \mathrm{~cm}$ ) with soils and litters collected from their natural habitats. In October and December 2016, we manually collected the fresh fallen leaf litter of the dominant oak tree (Q. variabilis) every 7 days from at least 25 individual trees. These litters were well mixed and "incubated" in a box under ambient temperature with moisture content at the field capacity until July 2017 . The incubation mimicked the natural processes and allowed the leaching of tannins from the litter, making it more favorable to the millipedes. At the time of leaf litter collection, approximately $6 \mathrm{~kg}$ of surface organic soils (0$10 \mathrm{~cm})$ were collected using soil cores $(5 \mathrm{~cm}$ diameter and 10 $\mathrm{cm}$ depth) at 25 randomly selected sites. All the soil samples were well mixed, air-dried, and sieved (2 $\mathrm{mm}$ mesh).
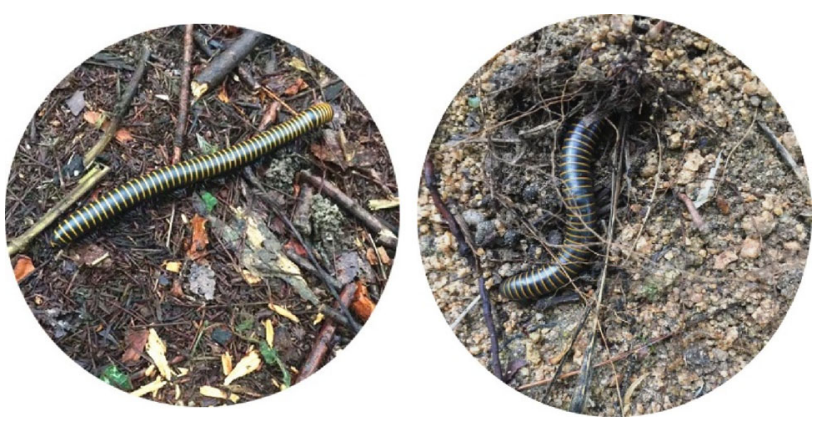

Fig. 1 The natural present of millipede species Spirobolus formosae (subsp. formosae Keeton, 1960) used in the present study in the temperate forest. The left figure, millipede walking in natural conditions; The right figure, millipede burrowing. 


\subsection{Experimental design}

In the present study, we constructed eight microcosms $(16 \mathrm{~cm}$ diameter and $20 \mathrm{~cm}$ of depth) that contained $500 \mathrm{~g}$ of soil (airdried weight) and $5 \mathrm{~g}$ of litters (oven-dried weight), using cylindrical plastic container. Two treatments were set up, one with nitrogen addition and another without nitrogen addition (control), to investigate how nitrogen deposition affects the microbial community and enzyme activity in millipede faeces. Four microcosms were randomly assigned to nitrogen addition treatment (four replicates), and the remaining four microcosms were treated as control. Before adding millipede to each microcosm, soil water content was adjusted to reach $60 \%$ of field capacity. To ensure homogeneous litter humidity, the leaf litter for each individual microcosm was soaked for 24 $\mathrm{h}$ in $250 \mathrm{~mL}$ deionized water, drained, and then added on top of the soil. Then after a $24 \mathrm{~h}$ incubation, two healthy (active, without damage) millipedes of similar weight were added to each microcosm. Before adding to the microcosm, the millipedes were placed in an empty box for $48 \mathrm{~h}$ for clearing their guts. We first incubated the microcosms to recover the activity of the millipedes. After one week of incubation, we separated the microcosms randomly into two groups, each including four microcosms as replicates. We added $\mathrm{N}$ solution to one of the groups of the microcosms to simulate nitrogen deposition ( $\mathrm{N}$-treatment). Equal amount of deionized water was added to the other group of microcosms (control, CK; no $\mathrm{N}$ addition) (Fig. 2). The nitrogen solution was made from
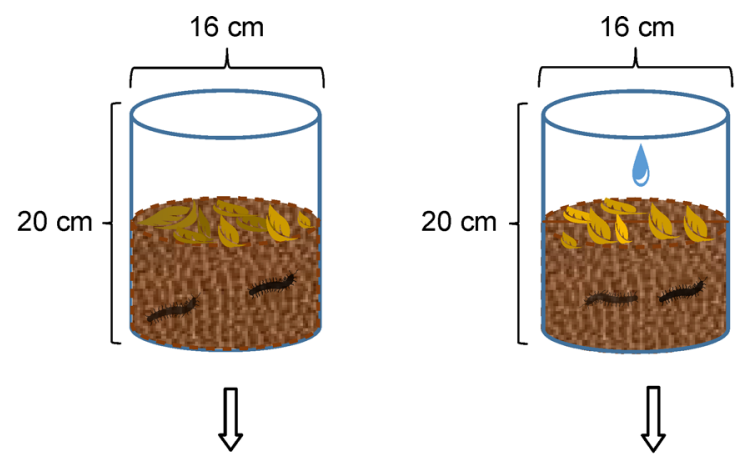

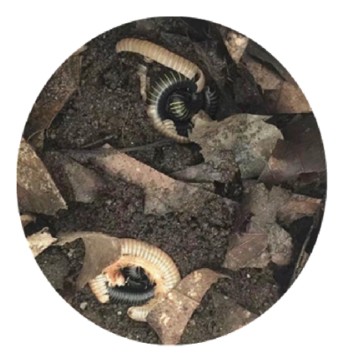

CK

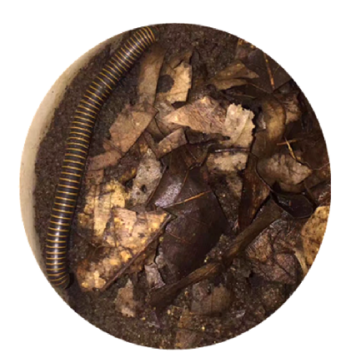

N
Fig. 2 The illustration of the experimental design, the size of the microcosm used, and the activity of millipede during the experiment in the study. $\mathrm{CK}$, control; $\mathrm{N}$, nitrogen addition treament.
$\mathrm{NH}_{4} \mathrm{NO}_{3}$. The $\mathrm{N}$-treatment received $0.10048 \mathrm{~g}$ nitrogen (equivalent to $50 \mathrm{~kg} \mathrm{~N} \mathrm{ha}^{-1} \mathrm{yr}^{-1}$ ) for each microcosm during the experiment, the same rate as used in a canopy nitrogen addition experiment conducted in this region (Zhang et al., 2015). The $\mathrm{N}$ solutions were stored in sterile plastic bottles at $4^{\circ} \mathrm{C}$. We sprayed $10 \mathrm{~mL}$ solution every 3 days. The experiment was terminated after 45 days when about $2 / 3$ of the litter was consumed by the millipedes.

\subsection{Faeces collection and chemical analysis}

At the end of the experiment, millipede faecal pellets were collected carefully. For each microcosm, the faecal pellets were well mixed and separated into three parts. One part was air-dried for chemical analysis, another part was stored at $4^{\circ} \mathrm{C}$ for the assay of enzymes activities, and the last part was freeze-dried for phospholipid fatty acid (PLFA) analysis.

The $\mathrm{pH}$ of the faeces was measured in a soil/deionized water suspension (1:2.5) by $\mathrm{pH}$ meter (Mettler Toledo, Shanghai, China). The carbon content was measured using the oxidation-heating method. In brief, $0.1 \mathrm{~g}$ of air-dried sample of faeces $(<0.15 \mathrm{~mm})$ was fist oxidize in $\mathrm{K}$ dichromate- sulphuric acid solution at $135^{\circ} \mathrm{C}$ for $45 \mathrm{~min}$. Then the resulting solution after digestion was titrated with $\mathrm{Fe}\left(\mathrm{NH}_{4}\right)_{2}\left(\mathrm{SO}_{4}\right)_{2}$ solution to determine the remaining dichromate. The carbon content in faeces samples was calculated based on the amount of $\mathrm{Fe}\left(\mathrm{NH}_{4}\right)_{2}\left(\mathrm{SO}_{4}\right)_{2}$ solution used in the titration (Lu, 2000). Total nitrogen was determined by Kjeldahl method after digestion of faeces samples in concentrated $\mathrm{H}_{2} \mathrm{SO}_{4}$ solution at $360^{\circ} \mathrm{C}(\mathrm{Lu}, 2000)$. Phosphorus was determined with UV-vis spectrophotometer at $712 \mathrm{~nm}$ using a molybdenum blue method. $0.1 \mathrm{~g}$ faeces samples was first digested by $\mathrm{HClO}_{4}$ solution at $200^{\circ} \mathrm{C}$. Then the $\mathrm{pH}$ of the resulting extracts was adjusted to $\sim 5$ with $\mathrm{NaOH}$ and $\mathrm{HCl}$ solution. The phosphorus concentration in the extracts was measured with spectrophotometer at $712 \mathrm{~nm}$ after adding 8 $\mathrm{mL}$ of the color developing solution ( $\mathrm{Lu}, 2000)$. For the dissolved organic carbon, nitrogen and phosphorus, the faeces were first extracted by $30 \mathrm{~mL}$ of distilled water for 30 min. Then dissolved organic carbon and nitrogen in the extracts were measured by Total Organic Carbon (TOC) analyzer. The dissolved phosphorus in the extracts was measured by the molybdenum blue method as described above.

\subsection{PLFA analysis}

PLFA biomarkers were used to represent the microbial community structure in the millipede faeces (Bossio and Scow, 1998). The lipids in each freeze-dried faeces sample were extracted in a single-phase mixture of chloroform: methanol:phosphate buffer (1:2:0.8 by volume; $\mathrm{pH}=7.4)$. We used a gas chromatograph equipped with a flameionisation detector to analyze the extracts (Agilent 6890, Agilent Technologies, Palo Alto, CA, USA). The abundance of individual PLFAs was expressed as nmol PLFAs $\mathrm{g}^{-1}$ dry faeces $\left(\mathrm{nmol} \mathrm{g}^{-1}\right)$. Then, the sum of all individual PLFAs was 
used as a measure of viable total microbial biomass (Frostegård and Bååth, 1996). Fungi (F) were represented by $18: 2 \omega 6,9 c, 16: 1 \omega 5 c, 18: 1 \omega 9 c, 18: 3 \omega 6 c(6,9,12)$ (Bååth and Anderson, 2003; Sakamoto et al., 2004). Actinomycetes (A) stood for 16:0 10Me, 18:0 10Me, 17:0 10Me (Diepen et al., 2010; Cusack et al., 2011). Gram-positive bacteria $\left(\mathrm{G}^{+}\right)$were indicated by i-14:0, 14:0, i-15:0, a-15:0, 15:0, i-17:0, a-16:0, a$17: 0$, and $\mathrm{i}-16: 0$. Gram-negative bacteria $\left(\mathrm{G}^{-}\right)$were represented by $16: 1 \omega 7 c$, cy $17: 0,18: 1 \omega 9 c, 18: 1 \omega 7 c, 16: 1 \omega 6 c$, and 17:1w8c (Frostegård and Bååth, 1996; Zak et al., 1996; Zelles, 1997). Bacteria(B) equal to $\mathrm{G}^{+}$plus $\mathrm{G}^{-} \cdot \mathrm{G}^{+}: \mathrm{G}^{-}$ratio and $F: B$ ratio represented the microbial community structure (Frostegård and Bååth, 1996).

\subsection{Oxidase activity analysis}

Activities of two oxidase, phenol oxidase $(\mathrm{PO})$ and peroxidase (POD), were assayed using the method described by SaiyaCork et al. (2002). Briefly, sample suspensions were prepared by adding $0.5 \mathrm{~g}$ of fresh faeces into $80 \mathrm{~mL}$ of $50 \mathrm{mM}$ acetate buffer ( $\mathrm{pH}$ 5.0) and homogenized for $10 \mathrm{~min}$. The resulting suspensions were continuously stirred using a magnetic stir plate while $200 \mathrm{~mL}$ aliquots were dispensed into 96-well microplates. Phenol oxidase and peroxidase activities were measured spectrophotometrically using L-3, 4-dihydroxyphenylalanine (DOPA) as the substrate after $24 \mathrm{~h}$ incubation in the dark at $20^{\circ} \mathrm{C}$. Activity was expressed in units of $\mathrm{nmol} \mathrm{h} \mathrm{h}^{-1} \mathrm{~g}^{-1}$.

\subsection{Data analysis}

Statistical analyses were performed using Past 3.0. An one way ANOVA $(n=4)$ was used to test the differences between the two treatments ( $\mathrm{CK}$ and $\mathrm{N}$ addition), and the pairwise comparisons (between the control and nitrogen addition treatment) was conducted using a Tukey's HSD test. Figures were produced with Origin 9.1. The relationship between microbial community structure and enzyme activity and physical and chemical properties of faeces were analyzed using Redundancy Analysis (RDA).

\section{Results}

\subsection{Chemical properties of faeces}

Nitrogen addition significantly decreased the carbon content in millipede faeces $(P<0.001$, Tukey's HSD test), but had no effect on total nitrogen content, resulting in a significant decrease in the ratio of $\mathrm{C}: \mathrm{N}$ in millipede faeces $(P<0.001$, Tukey's HSD test) (Table 1). Nitrogen addition also decreased the dissolved organic carbon and nitrogen, but the effect was significant only for dissolved nitrogen $(P<0.001$, Tukey's HSD test) (Table 1). However, nitrogen addition had no significant effects on $\mathrm{pH}$, and total and dissolved phosphorus in millipede faeces.

\subsection{Microbial community composition}

The dominant microbial groups in millipede faeces were bacteria (Fig. 3). Nitrogen addition increased the proportion of bacteria from $79 \%$ to $85 \%$, while decreasing the proportion of fungi and actinomycetes in the millipede faeces (Fig. 3).

$\mathrm{N}$ addition had no effect on the total microbial biomass (total PLFA content) in millipede faeces (Fig. 4A). The biomass of total bacteria, $\mathrm{G}^{+}$and $\mathrm{G}^{-}$bacterial groups, and the structure of the bacterial community in millipede faeces were also not significantly affected by nitrogen addition (Fig. 4C, F, G, H). However, nitrogen addition markedly decreased the fungal biomass in millipede faeces $(P<0.01$, Tukey's HSD test), resulting in significant reduction of the $F: B$ ratio of the microbial community $(P<0.05$, Tukey's HSD test)(Fig. 4B, $D)$. Nitrogen addition also significantly decreased the biomass of actinomycetes in millipede faeces $(P<0.01$, Tukey's HSD test) (Fig. 4E).

\subsection{Oxidase activity}

Enzyme activity is one of the most important indicators of soil microbial activity, and the two oxidase considered in this study, phenol oxidase and peroxidase, were primarily produced by fungi. In the present study, activities of both phenol oxidase and peroxidase were significantly reduced by $\mathrm{N}$ addition in millipede faeces $(P<0.01$, Tukey's HSD test) (Fig. 5), which was consistent with the decreased fungi biomass after nitrogen addition (Fig. 4D).

3.4 The relationships between chemical properties and microbial community composition and activity

RDA indicated that the chemical properties explained $98.7 \%$ of the variance of microbial properties (community structure and enzyme activity) in millipede faeces, with axis 1 explaining almost all the variance $(96.7 \%)$ and axis 2 explaining only $2 \%$ of the variance (Fig. 6). RDA showed that changes in microbial community structure $\left(\mathrm{F}: \mathrm{B}\right.$ and $\left.\mathrm{G}^{+} / \mathrm{G}^{-}\right)$in millipede faeces can be significantly explained by the $\mathrm{C} / \mathrm{N}$ ratio (Monte

Table 1 Chemical properties of millipede faeces (values are means $\pm \mathrm{se}, n=4)$ in control and nitrogen addition treatment.

\begin{tabular}{|c|c|c|c|c|c|c|c|c|}
\hline Treatment & $\mathrm{pH}$ & $\mathrm{FOC} /(\mathrm{g} / \mathrm{kg})$ & $\mathrm{TN} /(\mathrm{g} / \mathrm{kg})$ & TP /(g/kg) & $\mathrm{DOC} /(\mathrm{mg} / \mathrm{kg})$ & DTN/(mg/kg) & $\mathrm{DTP} /(\mathrm{mg} / \mathrm{kg})$ & $\mathrm{C} / \mathrm{N}$ \\
\hline$\overline{\mathrm{CK}}$ & $4.89 \pm 0.11 \mathrm{a}$ & $75.88 \pm 12.59 a$ & $7.86 \pm 2.70 a$ & $0.54 \pm 0.11 \mathrm{a}$ & $379.07 \pm 163.68 a$ & $575.61 \pm 167.04 a$ & $0.01 \pm 0.01 a$ & $9.65 \pm 1.80 a$ \\
\hline $\mathrm{N}$ & $4.64 \pm 0.61 a$ & $20.58 \pm 3.83 b$ & $6.11 \pm 3.05 a$ & $0.51 \pm 0.17 a$ & $135.62 \pm 66.12 a$ & $137.47 \pm 64.23 b$ & $0.03 \pm 0.00 \mathrm{a}$ & $3.37 \pm 1.33 b$ \\
\hline
\end{tabular}

CK, control; N, N addition; FOC, faeces organic carbon; TN, total nitrogen; TP, total phosphorus; DOC, dissolved organic carbon; DTN, dissolved total nitrogen; DTP, dissolved total phosphorus; $\mathrm{C} / \mathrm{N}$, organic carbon/total nitrogen. Different lowercase letters represent significant differences $(P<0.05$, Tukey's HSD test). 


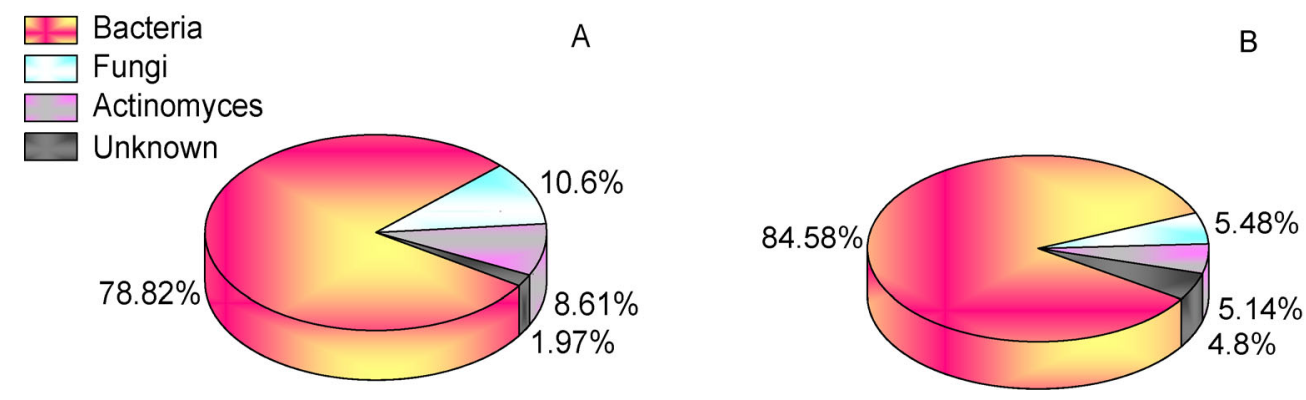

Fig. 3 Proportion of microbial groups in millipede faeces. $(A)$ is control, and $(B)$ is $N$ addition treatment.
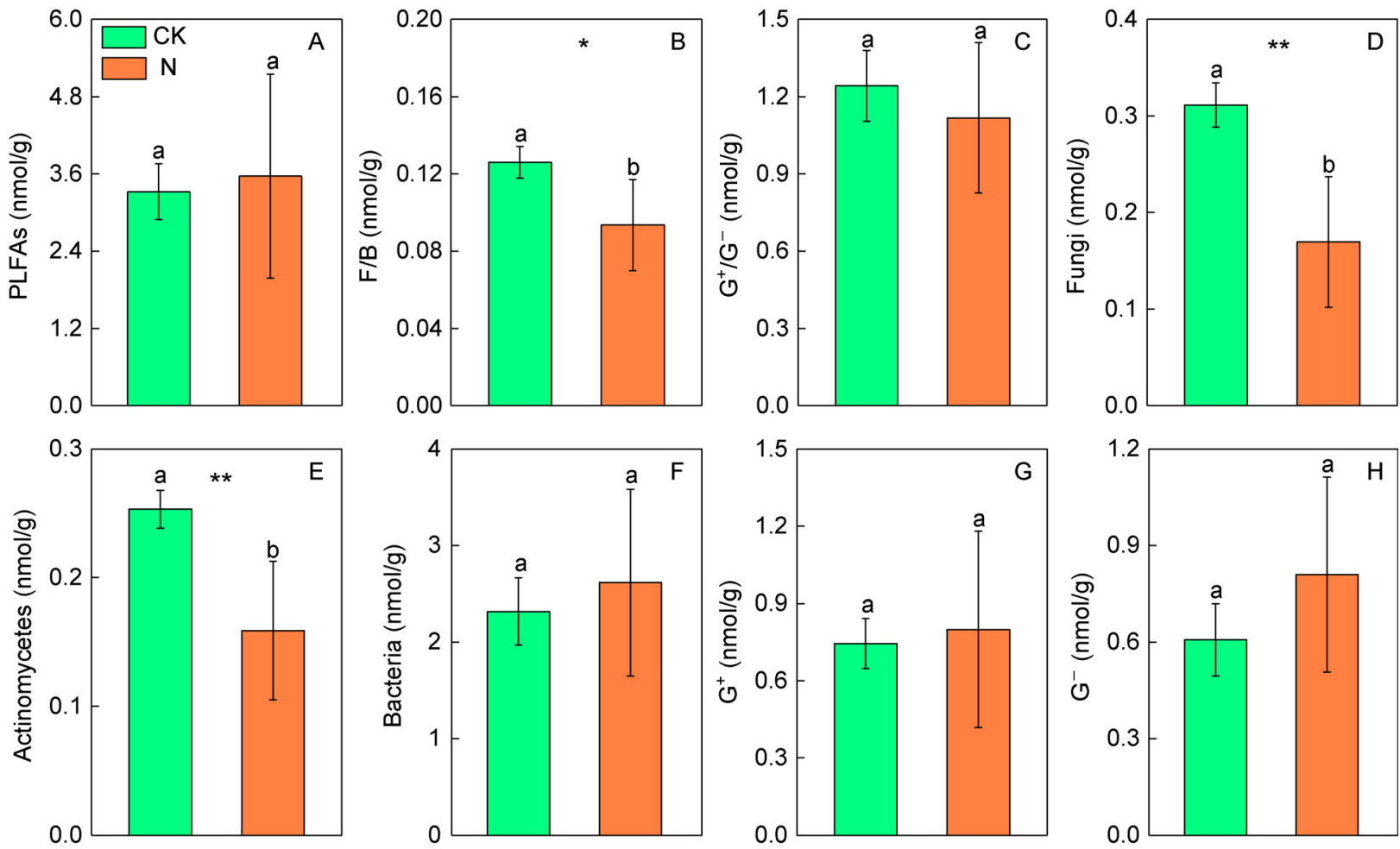

Fig. 4 PLFA of faeces. Different lowercase letters represent significant differences ( ${ }^{*}$ represents $P<0.05$, ${ }^{* *}$ represents $P<0.01$, Tukey's HSD test). F, fungi; B, bacteria; PLFAs: total PLFA; $\mathrm{G}^{+}$, Gram-positive bacteria; $\mathrm{G}^{-}$, Gram-negative bacteria; $F / B$, fungi:bacteria; $\mathrm{G}^{+} / \mathrm{G}^{-}$, Gram-positive bacteria: Gram-negative bacteria.

Carlo replacement test, $P<0.05)$, and changes in enzyme activities can be significantly explained by faeces organic carbon content (Monte Carlo replacement test, $P<0.05$ ).

\section{Discussion}

Our study showed that bacteria dominated the microbial community in millipede faeces, irrespective of whether nitrogen was added. This is consistent with the results from previous studies (Byzov et al., 1998). Several reasons can explain why bacteria are the dominant microbial groups in millipede faeces. First, considering the mouthparts of millipedes, the fungal hyphae colonized in the litter could get damaged by millipedes when they feeding and ingesting the litter (Crowther et al., 2011). Second, as some recent studies have suggested, millipedes and other soil invertebrates are most likely calcium-limited, and therefore, they need to assimilate more fungi, which are rich in calcium (Cromack et al., 1977), to meet their physiological needs. Third, the hindgut of millipedes offers favorable conditions for bacterial growth; even if the bacteria are killed and assimilated in the foregut, they could quickly recover in the hindgut and get egested in the faeces (Byzov et al., 1998). In addition, an organic and nutrient "hot spot," which can stimulate bacterial growth, can be formed when millipede faeces were deposited on the soil surface.

Millipede faeces are abundant in temperate forests, which act as a link between litter transformation and soil 

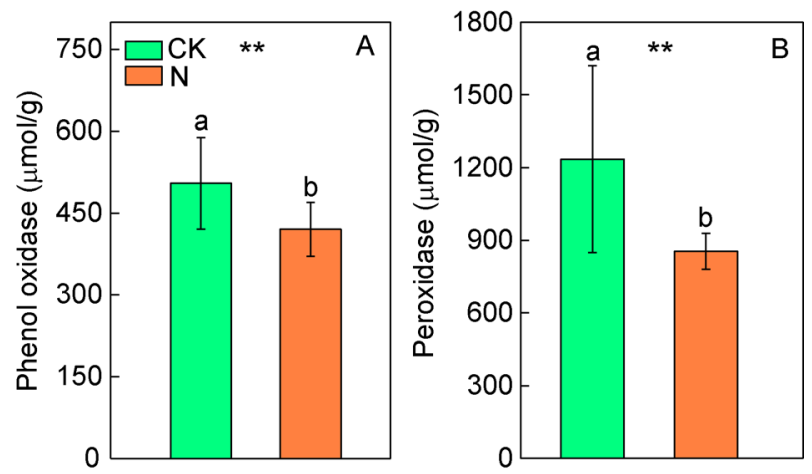

Fig. 5 Oxidase activity in faeces (** represents $P<0.01$, Tukey's HSD test). (A) is phenol oxidase activity, and (B) is peroxidase activity.

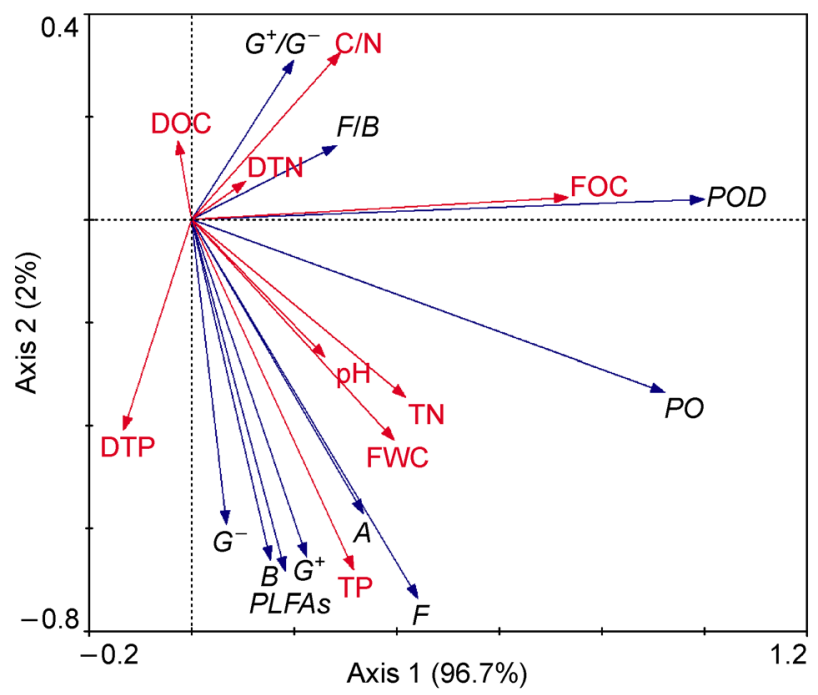

Fig. 6 Redundancy analysis of microbial community and oxidase with chemical variables of faeces. The chemical variables (red line) were used to explain the changes of microbial community structure and oxidase activity (blue line). DOC, dissolved organic carbon; DTN, dissolved total nitrogen; FOC, faeces organic carbon; TN, total nitrogen; FWC, faeces water content; TP, total phosphorus; DTP, dissolved total phosphorus; $\mathrm{C} / \mathrm{N}$, organic carbon/total nitrogen; $\mathrm{POD}$, peroxidase; $\mathrm{PO}$, phenol oxidase; F, fungi; A, actinomycetes; $B$, bacteria; PLFAs: total PLFA; $\mathrm{G}^{+}$, Gram-positive bacteria; $\mathrm{G}^{-}$, Gram-negative bacteria; $\mathrm{F} / \mathrm{B}$, fungi : bacteria; $\mathrm{G}^{+} / \mathrm{G}^{-}$, Gram-positive bacteria: Gram-negative bacteria. The red lines indicate the explanatory variables; the blue lined indicate the explained variables.

humification. Some previous studies have underlined their importance in soil carbon stabilization and nutrient dynamics (Anderson and Bignell., 1980). However, these previous studies have mainly focused on the effects of nitrogen deposition on soil and litter microbial properties (Bai et al., 2007). Our study is, thus, the first to explore how nitrogen addition affects the microbial community and enzyme activities in millipede faeces. Our findings indicate that nitrogen deposition can significantly affect microbial community structure $(F: B)$ and activity in millipede faeces.

Another important and interesting finding in our study is that nitrogen addition significantly decreased fungal biomass in millipede faeces. Fungi are one of the most important drivers of faeces decomposition. Our findings suggest that excess nitrogen input can inhibit fungal growth in millipede faeces possibly by two mechanisms; one, through the millipede physiology (assimilation), and the other through chemical changes in the faeces. The excess nitrogen input resulted in rich nitrogen content of the litter, which increased the assimilation efficiency of the millipedes. Therefore, more fungi colonized in the litter were ingested by millipedes in a nitrogen-enriched environment and were assimilated in the gut, resulting in the presence of less fungi in the faeces in nitrogen enriched environment than under natural conditions. In addition, nitrogen addition significantly reduced the total and dissolved carbon content of millipede faeces, which possibly limit fungal growth, as fungi are more likely to be carbon limited than bacteria.

The composition of a microbial community is closely related to its functions. It is well established that fungi are the primary producers of oxidase (Osono, 2007; Sinsabaugh, 2010), including phenol oxidase and peroxidase studied here. In our study, the fungi with oxidase activity were significantly decreased in millipede faeces under nitrogen addition. Therefore, the decreased fungal biomass in millipede faeces under nitrogen addition can well explain the second important finding in our study: nitrogen deposition markedly reduces the activities of two important oxidases - phenol oxidase and peroxidase. These two fungi-produced enzymes are responsible for the biodegradation of lignin and other recalcitrant substances (Osono, 2007; Sinsabaugh, 2010). Nitrogen deposition significantly decreased the fungal biomass and the activities of phenol oxidase and peroxidase in millipede faeces, which has important implications for ecosystem functions. These reductions in fungal biomass and oxidase activity under nitrogen deposition would greatly suppress decomposition of the millipede faeces, which could enhance the level of humification and carbon stabilization. Considering the vast amount and wide distribution of millipedes in terrestrial ecosystems and their low assimilation efficiencies (David and Gillon, 2002), nitrogen-induced millipede faeces stabilization could contribute significantly to soil carbon sequestration and reduction in greenhouse gas emissions. However, the activities of millipedes have been largely overlooked in the existing literature on global change ecology and ecosystem ecology. A more detailed and comprehensive understanding of the activities of millipedes and incorporating them in modeling studies in the future would greatly enhance our understanding of the dynamics of soil ecosystem functioning in a changing world.

\section{Conclusion}

In the present study, we explored for the first time how 
nitrogen addition affects microbial community and enzyme activities in millipede faeces. Our study clearly indicated that nitrogen deposition can significantly affect microbial community structure $(F: B)$ and activity in millipede faeces. The most important and interesting finding in our study is that nitrogen addition significantly decreased fungal biomass in millipede faeces, which well explains the marked reduction in the activities of two important oxidases: phenol oxidase and peroxidase. As fungi and their produced oxidase play vital roles in the biodegradation of lignin and other recalcitrant substances, nitrogen-induced reductions in fungal biomass and oxidase activity under nitrogen deposition would greatly suppress the decomposition of the millipede faeces, which could enhance soil humification and carbon stabilization and reduce greenhouse gas emission. However, the activities of millipedes have been largely overlooked in the present global change ecology and ecosystem ecology. Therefore, it is worthwhile to pay more attention to the activities of millipede and understand how these activities may change under future global changes .

\section{Acknowledgments}

This research was funded by the National Natural Science Foundation of China (31700416, 31470559 and 31600434).

\section{Conflict of interest statement}

The authors declare no conflict of interest.

\section{References}

Anderson, J.M., Bignell, D.E., 1980. Bacteria in the food, gut contents and faeces of the litter-feeding millipede Glomeris marginata (Villers). Soil Biology \& Biochemistry 12, 251-254.

Bååth, E., Anderson, T.H., 2003. Comparison of soil fungal/bacterial ratios in a $\mathrm{pH}$ gradient using physiological and PLFA-based techniques. Soil Biology \& Biochemistry 35, 955-963.

Bai, Z., Zhang, X., He, H., Yan, Y., Hou, S., Chen, Y., Xie, H., 2007. Effects of long-time niterogen fertilizer application on NLFA and PLFA in mollisol farmland. Acta Pedologica Sinical 44, 709-716.

Bossio, D.A., Scow, K.M., 1998. Impacts of carbon and flooding on soil microbial communities: phospholipid fatty acid profiles and substrate utilization patterns. Microbial Ecology 35, 265-278.

Byzov, B.A., Kurakov, A.V., Tretyakova, E.B., Thanh, V.N., Luu, N.D. T., Rabinovich, Y.M., 1998. Principles of the digestion of microorganisms in the gut of soil millipedes: Specificity and possible mechanisms. Applied Soil Ecology 9, 145-151.

Carreiro, M.M., Sinsabaugh, R.L., Repert, D.A., Parkhurst, D.F., 2000. Microbial enzyme shifts explain litter decay responses to simulated nitrogen deposition. Ecology 81, 2359-2365.

Cromack, K., Sollins, P., Todd, R.L., Fogel, R., Todd, A.W., Fender, W. M., 1977. The role of oxalic acid and bicarbonate in calcium cycling by fungi and bacteria: Some possible implications for soil animals. Ecological Bulletins 25, 246-252.
Crowther, T.W., Boddy, L., Jones, T.H., 2011. Species-specific effects of soil fauna on fungal foraging and decomposition. Oecologia 167, 535-545.

Cusack, D.F., Silver, W.L., Torn, M.S., Burton, S.D., Firestone, M.K., 2011. Changes in microbial community characteristics and soil organic matter with nitrogen additions in two tropical forests. Ecology 92, 621-632.

David, J.F., 2014. The role of litter-feeding macroarthropods in decomposition processes: a reappraisal of common views. Soil Biology \& Biochemistry 76, 109-118.

David, J.F., Gillon, D., 2002. Annual feeding rate of the millipede Glomeris marginata, on holm oak (Quercus ilex) leaf litter under Mediterranean conditions. Pedobiologia 46, 42-52.

Diepen, L.T., Lilleskov, E.A., Pregitzer, K.S., Miller, R.M., 2010. Simulated nitrogen deposition causes a decline of intra-and extraradical abundance of arbuscular mycorrhizal fungi and changes in microbial community structure in northern hardwood forests. Ecosystems (New York, N.Y.) 13, 683-695.

Fields, S., 2004. Global nitrogen: cycling out of control. Environmental Health Perspectives 112, A556-A563.

Frostegård, A., Bååth, E., 1996. The use of phospholipid fatty acid analysis to estimate bacterial and fungal biomass in soil. Biology and Fertility of Soils 22, 59-65.

IUSS Working Group WRB, 2015. World Reference Base for Soil Resources 2014, update 2015. International soil classification system for naming soils and creating legends for soil maps. FAO, Rome.

Jia, Y., Yu, G., He, N., Zhan, X., Fang, H., Sheng, W., Zuo, Y., Zhang, D., Wang, Q., 2014. Spatial and decadal variations in inorganic nitrogen wet deposition in China induced by human activity. Scientific Reports 4, 3763.

Liu, X., Zhang, Y., Han, W., Tang, A., Shen, J., Cui, Z., Vitousek, P., Erisman, J.W., Goulding, K., Christie, P., Fangmeier, A., Zhang, F., 2013. Enhanced nitrogen deposition over China. Nature 494, 459462.

Lu, R., 2000. Soil argrochemistry analysis protocoes. Beijing: China Agriculture Science Press.

Maraun, M., Scheu, S., 1996. Changes in microbial biomass, respiration and nutrient status of beech (Fagus sylvatica) leaf litter processed by millipedes (Glomeris marginata). Oecologia 107, 131-140.

Oravecz, O., 2002. A molecular approach in the analysis of the faecal bacterial community in an African millipede belonging to the family Spirostreptidae (Diplopoda). European Journal of Soil Biology 38, 67-70.

Osono, T., 2007. Ecology of ligninolytic fungi associated with leaf litter decomposition. Ecological Research 22, 955-974.

Rawlins, A.J., Bull, I.D., Ineson, P., Evershed, R.P., 2007. Stabilisation of soil organic matter in invertebrate faecal pellets through leaf litter grazing. Soil Biology \& Biochemistry 39, 1202-1205.

Rawlins, A.J., Bull, I.D., Poirier, N., Ineson, P., Evershed, R.P., 2006. The biochemical transformation of oak (Quercus robur) leaf litter consumed by the pill millipede (Glomeris marginata). Soil Biology \& Biochemistry 38, 1063-1076.

Saiya-Cork, K.R., Sinsabaugh, R.L., Zak, D.R., 2002. The effects of long term nitrogen deposition on extracellular enzyme activity in an 
acer saccharum, forest soil. Soil Biology \& Biochemistry 34, 1309 1315.

Sakamoto, K., lijima, T., Higuchi, R., 2004. Use of specific phospholipid fatty acids for identifying and quantifying the external hyphae of the arbuscular mycorrhizal fungus Gigaspora rosea. Soil Biology \& Biochemistry 36, 1827-1834.

Shi, L., Zhang, H., Liu, T., Mao, P., Zhang, W., Shao, Y., Fu, S., 2018. An increase in precipitation exacerbates negative effects of nitrogen deposition on soil cations and soil microbial communities in a temperate forest. Environ Pollut 235, 293-301.

Shi, L., Zhang, H., Liu, T., Zhang, W., Shao, Y., Ha, D., Li, Y., Zhang, C., Cai, X.A., Rao, X., Lin, Y., Zhou, L., Zhao, P., Ye, Q., Zou, X., Fu, S., 2016. Consistent effects of canopy vs. understory nitrogen addition on the soil exchangeable cations and microbial community in two contrasting forests. Science of the Total Environment 553, 349-357.

Sierwald, P., Bond, J.E., 2007. Current status of the Myriapod class diplopoda (millipedes): taxonomic diversity and phylogeny. Annual Review of Entomology 52, 401-420.

Sinsabaugh, R.L., 2010. Phenol oxidase, peroxidase and organic matter dynamics of soil. Soil Biology \& Biochemistry 42, 391-404.
Tajovsky, K., Santruckova, H., Hanel, L., Balik, V., Lukesova, A., 1992. Decomposition of faecal pellets of the millipede Glomeris hexasticha (Diplopoda) in forest soil. Pedobiologia 36, 146158.

Treseder, K.K., 2008. Nitrogen additions and microbial biomass: a meta-analysis of ecosystem studies. Ecology Letters 11, 11111120.

Ye, Y., Li, P., Qu, W., 2014. Scientific survey on Henan Jigongshan Nature Reserve. Beijing: Science press.

Zak, D.R., Ringelberg, D.B., Pregitzer, K.S., Randlett, D.L., White, D. C., Curtis, P.S., 1996. Soil microbial communities beneath populus grandidentata grown under elevated atmospheric $\mathrm{CO}_{2}$. Ecological Applications 6, 257-262.

Zelles, L., 1997. Phospholipid fatty acid profiles in selected members of soil microbial communities. Chemosphere 35, 275-294.

Zhang, W., Shen, W., Zhu, S., Wan, S., Luo, Y., Yan, J., Wang, K., Liu, L., Dai, H., Li, P., Dai, K., Zhang, W., Liu, Z., Wang, F., Kuang, Y., Li, Z., Lin, Y., Rao, X., Li, J., Zou, B., Cai, X., Mo, J., Zhao, P., Ye, Q., Huang, J., Fu, S., 2015. CAN canopy addition of nitrogen better illustrate the effect of atmospheric nitrogen deposition on forest ecosystem? Scientific Reports 5, 11245. 